\title{
Daytime habitat selection for juvenile parr brown trout (Salmo trutta) in small lowland streams
}

\author{
J. Conallin ${ }^{(1), \star}$, E. Boegh ${ }^{(1)}$, M. Olsen ${ }^{(2)}$, S. Pedersen ${ }^{(3)}$, M.J. Dunbar ${ }^{(4)}$, \\ J.K. Jensen ${ }^{(5)}$
}

Received October 30, 2013

Revised February 10, 2014

Accepted February 11, 2014

\section{ABSTRACT}

Key-words:

Daytime refugia, habitat selection, habitat suitability indices, predation, water management
Physical habitat is important in determining the carrying capacity of juvenile brown trout, and within freshwater management. Summer daytime physical habitat selection for the parr lifestage $(7-20 \mathrm{~cm})$ juvenile brown trout (Salmo trutta) was assessed in 6 small lowland streams. Habitat preference was determined for the four variables; water velocity, water depth, substrate and cover, and the preferences for physical habitat selection were expressed in terms of habitat suitability indices (HSI's). The statistical confidence of HSI's was evaluated using power analysis. It was found that a minimum of 22 fish observations was needed to have statistical confidence in the HSls for water depth, and a minimum of 92 fish observations for water velocity during daytime summer conditions. Generally parr were utilising the deeper habitats, indicating preference for deeper water. Cover was also being selected for at all sites, but selection was inconsistent among sites for the variables substrate and velocity. The results indicate that during daytime summer conditions water depth is a significant variable for parr habitat selection in these small lowland streams, with cover also being important. Therefore, daytime refugia may be a critical limiting factor for parr in small lowland streams, and important for stream management actions under the Water Framework Directive.

RÉSUMÉ

Sélection de l'habitat diurne par les juvéniles de truite (Salmo trutta) dans les petits ruisseaux de plaine

\section{Mots-clés :}

Refuges de jour, sélection de l'habitat, indices de qualité d'habitat, prédation, gestion de l'eau
L'habitat physique est important dans la détermination de la capacité d'accueil de la truite juvénile, et dans la gestion de l'eau. La sélection de l'habitat physique en journée estivale pour le stade tacon $(7-20 \mathrm{~cm})$ de truites juvéniles (Salmo trutta) a été évaluée dans 6 petits cours d'eau de plaine. La préférence de l'habitat a été déterminée pour quatre variables; la vitesse de l'eau, la profondeur de l'eau, le substrat et la couverture, et les préférences pour la sélection de l'habitat physique ont été exprimées en termes d'indices de qualité d'habitat (HSI). La confiance statistique de $\mathrm{HSI}$ a été évaluée en utilisant l'analyse de puissance. II a été trouvé qu'un minimum de 22 observations de poissons a été nécessaire pour

(1) Roskilde University, ENSPAC, 4000 Roskilde, Denmark

(2) Geological Survey of Denmark and Greenland (GEUS), O. Voldgade 10, 1350 Copenhagen, Denmark

(3) Technical University of Denmark - AQUA, National Institute of Aquatic Resources, Dept. of Inland Fisheries, 8600 Silkeborg, Denmark

(4) Centre for Ecology and Hydrology, Wallingford OX10 8BB, UK

(5) DHI Water Environment and Health, 2970 Horsholm, Denmark

* Corresponding author: pclsmoo@hotmail.com 
obtenir une bonne estimation d'HSI pour la profondeur de l'eau, et un minimum de 92 observations de poissons pour la vitesse de l'eau au cours de conditions estivales diurnes. Généralement les tacons utilisent les habitats plus profonds, ce qui indique une préférence pour des eaux plus profondes. La couverture a été également choisie pour l'ensemble des sites, mais le choix était variable entre les sites pour les variables substrat et vitesse. Les résultats indiquent que pendant la journée en conditions estivales la profondeur de l'eau est une variable importante pour la sélection de l'habitat des tacons dans ces petits cours d'eau de plaine, avec le degré de couvert également important. Par conséquent, les refuges de jour peuvent être un facteur critique limitant pour les tacons dans les petits ruisseaux de plaine, et important pour les mesures de gestion des débits dans le contexte de la directive cadre sur l'eau.

\section{INTRODUCTION}

Good ecological status (GES) of surface waters is the overall aim of the European Water Framework Directive (WFD) (Commission, 2000), and this is assessed by using biological indicators (fish, macroinvertebrates, macrophytes and algae). Knowledge on the sensitivity of these biological indicators to hydromorphological conditions is needed to assess what are the limiting factors when GES is not achieved (Parasiewicz, 2007; Acreman and Ferguson, 2010).

Small ( $<5 \mathrm{~m}$ width) lowland streams are abundant in Europe. For example, in Denmark over $80 \%$ of the streams (app. $50000 \mathrm{~km}$ ) consist of small lowland streams (Sand-Jensen and Friberg, 2006). These small streams are important rearing areas for anadromous salmonid populations including brown trout (Salmo trutta) (Mortensen, 1977; Heggenes et al., 2002; Roussel and Bardonnet, 2002). Small streams are also particularly vulnerable to human impact such as water abstraction, agriculture, forestry, and channelisation (Brookes 1987; Olsen et al., 2009; Falke et al., 2011; Procopio, 2012) or the potential effects of climate change (Almodóvar et al., 2012; Bain and Jia 2012). Because brown trout are important socially, economically and ecologically within much of Europe, they are often used as the 'fish' indicator species for many of the national and EU environmental plans in both large rivers and small streams (Friberg et al., 2005; Conallin, 2009). However, most knowledge on brown trout physical habitat requirements is from studies in larger streams and rivers (Heggenes, 1988a; Heggenes et al., 1999; Armstrong et al., 2003; Parasiewicz and Dunbar, 2001). There is little knowledge on physical habitat requirements in small lowland streams that can be used to evaluate the effects of different water management actions such as water abstraction or stream restoration activities aimed at increasing stream flow and improving physical habitat conditions (Dunbar et al., 2001; Conallin et al., 2010a; Nislow and Armstrong, 2012).

Four habitat variables are known to affect the habitat selection of salmonids and carrying capacity in streams (Vezza et al., 2012); water depth (Kennedy and Strange, 1982; Heggenes, 1988a, 2002), water velocity (Heggenes and Traaen, 1988; Heggenes et al., 1999; Heggenes and Dokk, 2001), bed substrate (Heggenes, 1988b; Knapp and Preisler, 1999; Kondolf, 2000), and cover (Hubert et al., 1994; Bovee et al., 1998). However, differences in stream characteristics can influence the importance of these variables on brown trout habitat selection, i.e. it is not necessarily the same variables that are limiting in a large river as in a small stream. Consequently, it is important to know the habitat variables having the strongest influence on habitat selection depending on stream type (Dunbar et al., 2001). In this study, daytime field surveys of brown trout habitat use and availability were conducted in six small ( $<5 \mathrm{~m}$ width) lowland streams in Denmark during summer low flow conditions. The overall aim of the study was to assess the biological significance and consistency of brown trout habitat preference across the small lowland stream type, and its relevance to current and future water management. 


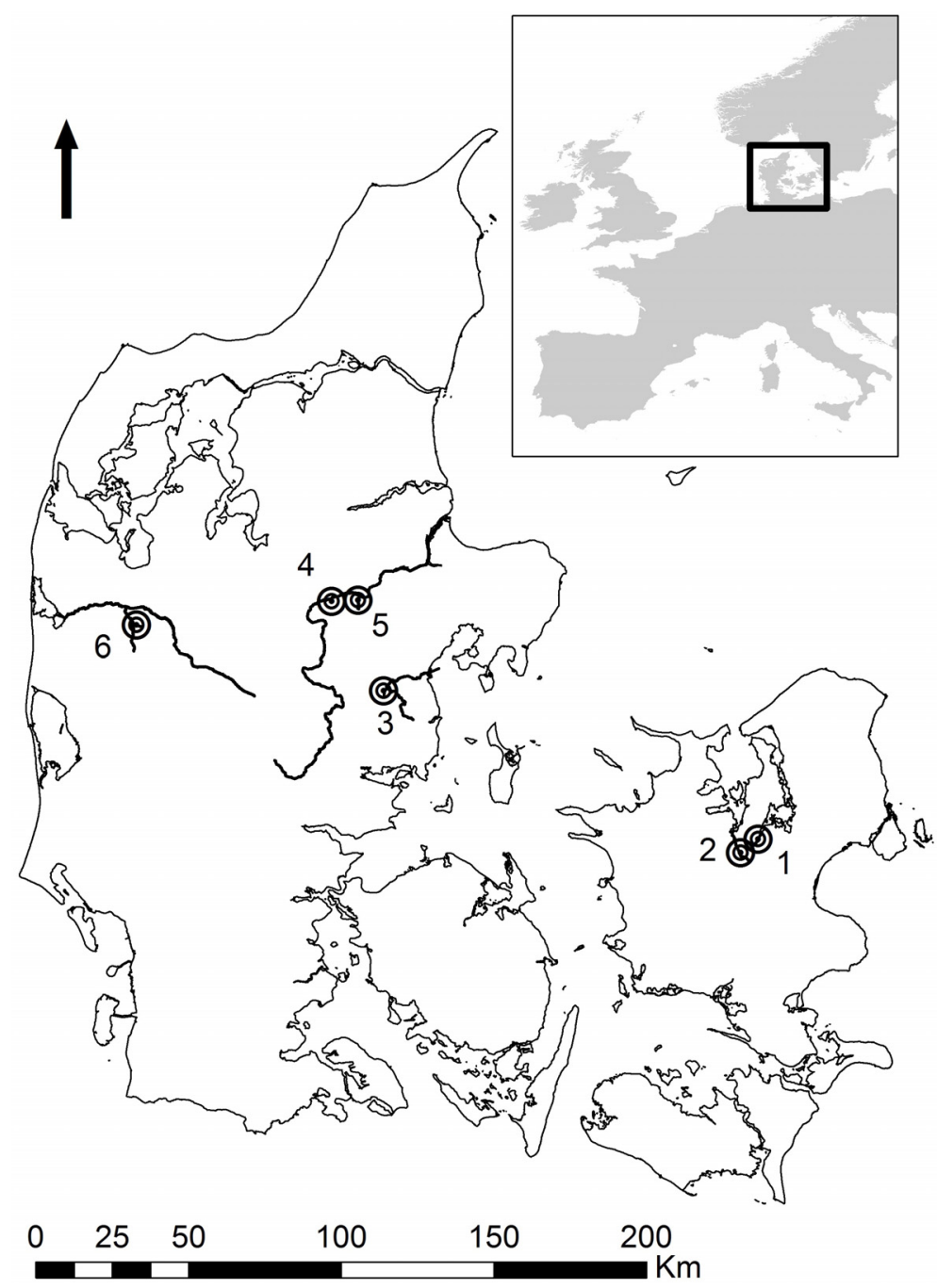

Figure 1

Location of six study sites situated in Denmark. All sites were in reaches that contained self-sustaining populations of brown trout.

\section{MATERIALS AND METHODS}

\section{> STUDY AREA}

Data were collected from a single site in six small lowland streams (average width $2 \mathrm{~m}$ ) in Denmark (Figure 1). All sites were within sections of typical brown trout small lowland streams with glacial deposits dominated by moraine loamy clays except for site 6 which was situated on the far western part of Denmark in a region where the geology is dominated by glacial outwash sands. Detailed descriptions of the habitat characteristics of the test sites are given in Table I. Bed substrate composition in all sites had high occurrence of sand ( $>28 \%$ cover), and varying levels of other substrates, except for site 6 which did not contain any boulder or cobble (Table I).

Self-sustaining anadromous brown trout was the dominant fish species in all of the sites. They spawn in the headwaters with a relatively small percentage of the population, mostly small precocious males, staying in the streams as residents. Juveniles $(<20 \mathrm{~cm}$ in total length) are therefore the most abundant life stage all year round, predominately parr $(7-20 \mathrm{~cm})$, except in the spring when large quantities of fry $(>7 \mathrm{~cm})$ dominate (Mortensen, 1977, 1982, 1985). Other fish species were present in all streams but in much lower numbers, including 


\section{Table I}

Characteristics of study streams; i.e. catchment area (A), mean altitude above sea level (MASL), mean discharge (Q), mean $\pm S E$ and range of the Wetted Width (WW), mean $\pm S E$ and maximum Depth (D), mean $\pm S E$ and the maximum value of velocity $(\mathrm{V})$, and the percentage distribution of the 6 substrate categories; Boulder (B), Cobble (Co), Pebble (P), Gravel (G), Sand (Sa) and Silt (S).

\begin{tabular}{|c|c|c|c|c|c|c|}
\hline Stream no & 1 & 2 & 3 & 4 & 5 & 6 \\
\hline $\begin{array}{l}\text { Name } \\
\text { of Stream }\end{array}$ & $\begin{array}{l}\text { Elverdams- } \\
\text { aen }\end{array}$ & $\begin{array}{l}\text { Hellig- } \\
\text { renden }\end{array}$ & Jeksen & Kjelbaek & Tjaerbaek & Stokvad \\
\hline$A\left(k^{2}\right)$ & 12.53 & 8.61 & 7.33 & 3.17 & 5.87 & 5.19 \\
\hline MASL (m) & 22 & 22 & 55 & 25 & 38 & 22 \\
\hline$Q\left(m^{3} \cdot s^{-1}\right)$ & 0.049 & 0.037 & 0.072 & 0.014 & 0.041 & 0.041 \\
\hline WW (m) & $\begin{array}{c}2.68 \pm 0.10 \\
(1.9-3.5)\end{array}$ & $\begin{array}{c}2.16 \pm 0.10 \\
(1.6-2.8)\end{array}$ & $\begin{array}{c}1.87 \pm 0.10 \\
(1.4-2.3)\end{array}$ & $\begin{array}{c}1.49 \pm 0.10 \\
(1.2-2.2)\end{array}$ & $\begin{array}{c}2.10 \pm 0.12 \\
(1.6-3.4)\end{array}$ & $\begin{array}{c}1.66 \pm 0.09 \\
(1.0-2.5)\end{array}$ \\
\hline$D(m)$ & $\begin{array}{c}0.13 \pm 0.01 \\
(0.57)\end{array}$ & $\begin{array}{c}0.10 \pm 0.01 \\
(0.50)\end{array}$ & $\begin{array}{c}0.13 \pm 0.01 \\
(0.31)\end{array}$ & $\begin{array}{c}0.08 \pm 0.01 \\
(0.31)\end{array}$ & $\begin{array}{c}0.12 \pm 0.01 \\
(0.41)\end{array}$ & $\begin{array}{c}0.23 \pm 0.01 \\
(0.49)\end{array}$ \\
\hline$V\left(m \cdot s^{-1}\right)$ & $\begin{array}{c}0.237 \pm 0.02 \\
(0.994)\end{array}$ & $\begin{array}{c}0.222 \pm 0.02 \\
(0.756)\end{array}$ & $\begin{array}{c}0.299 \pm 0.03 \\
(0.799)\end{array}$ & $\begin{array}{c}0.158 \pm 0.03 \\
(0.659)\end{array}$ & $\begin{array}{c}0.215 \pm 0.03 \\
(0.693)\end{array}$ & $\begin{array}{c}0.133 \pm 0.02 \\
(0.412)\end{array}$ \\
\hline Substrate S & 5 & 7 & 0 & 17 & 3 & 15 \\
\hline Substrate Sa & 29 & 43 & 32 & 36 & 75 & 62 \\
\hline Substrate G & 12 & 15 & 14 & 11 & 7 & 18 \\
\hline Substrate P & 30 & 23 & 22 & 20 & 11 & 5 \\
\hline Substrate Co & 20 & 11 & 18 & 14 & 3 & 0 \\
\hline Substrate B & 4 & 1 & 14 & 2 & 1 & 0 \\
\hline
\end{tabular}

European eel (Anguilla anguilla), European perch (Perca fluviatilis) and three-spined sticklebacks (Gasterosteidae aculeatus).

\section{> HABITAT AVAILABILITY AND USE}

Each site consisted of a $200 \mathrm{~m}$ stream section including pool, run and riffle stream habitat types. Habitat availability $(\mathrm{HA})$ data were collected at transects approximately every $10 \mathrm{~m}$ within the section representing each habitat type proportionately to its occurrence. For each transect the wetted width was measured perpendicular to the current. Across the transect, point measurements of water depth $(D)$, water velocity $(V)$, substrate composition $(S)$ and cover $(C)$ were carried out at intervals corresponding to $5,20,40,60,80$ and $95 \%$ of the wetted width. Water depth $(\mathrm{m})$ was measured using a measuring scale on a wading rod, and $V\left(\mathrm{~m} \cdot \mathrm{s}^{-1}\right)$ was measured using a Valeport 801 electromagnetic flow meter at a depth $60 \%$ of total water depth from the water surface corresponding to mean water column $V$. Water velocity $(V)$ was measured as part of the habitat availability survey (see below), and stream discharge calculated from cross-sectional velocity measurements (see below) using the CalQ software (Clausen and Jensen, 1994). Substrate composition and cover was visually assessed within a $0.25 \mathrm{~m} \times 0.25 \mathrm{~m}$ square. S-values were registered according to a modified Wentworth scale with assessment of the relative proportion of each of the categories: boulder (diameter $(\varnothing)>256 \mathrm{~mm})$, cobble $(\varnothing=64-256 \mathrm{~mm})$, pebble $(\varnothing=16-63 \mathrm{~mm})$, gravel $(\varnothing=2-15 \mathrm{~mm})$, sand $(\varnothing=0.06-1 \mathrm{~mm})$, and silt $(\varnothing<0.06 \mathrm{~mm})$ (Bain and Stevenson, 1999). Cover (C) was registered as present or absent according to three main categories; solid cover (i.e. boulder, wood and log jams, undercut bank) (SOL), reduced visibility cover (water surface tension) (REV), and no cover (NC).

To collect habitat use $(\mathrm{HU})$ data, single pass electrofishing was carried out using a $700 \mathrm{~W}$ DC bank-mounted Honda electrofisher. The operator moved upstream fishing the entire stream width capturing all stunned parr and marking their positions where first sighted with pegs. At each parr position, $D, V, S$ and $C$ was recorded same way as data collected for habitat availability. 


\section{>ANALYSES}

In order to assess if $\mathrm{HA}$ and $\mathrm{HU}$ sample sizes were of adequate size, a power analysis (Krebs, 1998) was carried out for $D$ and $V$ data for each site to assess the minimum sample size needed to detect an effect of a given parameter;

$$
n=\left(t_{\alpha} s / d\right)^{2}
$$

where $n=$ sample size required, $t_{\alpha}=$ Student's $t$-value $(p=0.05), s=$ standard deviation of habitat variable, and $d=$ desired absolute error. Estimates of $\mathrm{n}$ were evaluated using absolute error margins of 0.05 and $0.03\left(\mathrm{~m}^{2}\right.$ and $\left.\mathrm{m} \mathrm{s}^{-1}\right)$ respectively for $D$ and $V$.

In order to analyse whether there was disproportional use (preference) of habitats taking place, Mann-Whitney U-tests (Quinn and Keough, 2006) were applied to data from each site to compare the medians of $\mathrm{HA}$ and $\mathrm{HU}$ data for the variables $D, V$ and $S$. Substrate is originally a categorical variable but for this test, it was converted into a mean substrate index that could then be analyzed using this test. The Mann-Whitney U-test was not applicable to $C$. Two-way contingency tables were used to compare the distributions of the $\mathrm{HU}$ and $\mathrm{HA}$ data for all 4 types of habitat variables.

Univariate preference habitat suitability indices (HSI) were developed for each site for the parr lifestage and the habitat variables $D, V, S$ and $C$, following the procedure suggested by Bovee (1986). Habitat variables $D$ and $V$ were divided into $0.1 \mathrm{~m} \mathrm{or} \mathrm{m} \cdot \mathrm{s}^{-1}$ intervals, and habitat variables $S$ and $C$ used categorical intervals. Frequencies of $\mathrm{HU}$ and $\mathrm{HA}$ were calculated within each interval. The Forage Ratio (Edmondson and Winberg, 1971) was used to calculate an index of selection for each interval;

$$
P_{i}=U_{i} / A_{i}
$$

$P$ is an index of selection for each habitat variable interval $(i), U$ is the relative use of a specific habitat variable interval compared to all $\mathrm{HU}$ samples, and $A$ is the relative available habitat of a specific habitat variable interval compared to all $H A$ samples. The index of selection was normalized according to the highest calculated U/A ratio within each habitat variable and results were displayed graphically as HSIs.

Calculation of $P$ is sensitive to accurate representation of the full range of $H A$ especially extreme (rare) values. Therefore it was decided to group intervals when poor data availability caused spurious $P$ values. Consequently, if a) the number of $D$ and $V$ observations from the $H A$ sampling in an interval represented less than $10 \%$ of total $H A$ and $b$ ) the $95 \%$ confidence limits around this interval was found to be disproportionately wide compared to the other habitat intervals, then the data-poor interval was grouped with the neighbouring interval.

\section{RESULTS}

\section{> SAMPLE SIZE ANALYSIS OF HU AND HA DATA}

When sampling $\mathrm{D}$, adequate sample sizes were obtained for $\mathrm{HA}$ and $\mathrm{HU}$ for all sites to satisfy absolute error margins of 0.05 and $0.03 \mathrm{~m}$ (Table II). Velocities were much more varied and in general required higher sample sizes to satisfy desired absolute errors to $0.05 \mathrm{~m} \cdot \mathrm{s}^{-1}$, and sampling was not always adequate for $0.03 \mathrm{~m} \cdot \mathrm{s}^{-1}$ (Table II).

\section{> DAYTIME HABITAT SELECTION}

There was a significant difference between utilised $D$ and available $D$ in all sites indicating preference was occurring (Table III). Parr used greater median $D$ than available median $D$ indicating preference for the greatest water depths available. Regarding the preference for $D$ (Figure 2), all sites display a consistent increase in HSI with maximum preference occurring 
Table II

Observed $(N)$ and required $(n)$ sample sizes of $H A$ and $H U$ for depth $(D)$ and velocity $(V)$ of the 6 test streams. Required sample sizes are calculated for error levels of 0.05 and 0.03 respectively (see text). Bold values show the estimates of required sample sizes which were not fulfilled in this study.

\begin{tabular}{|l|c|c|c|c|c|c|c|c|c|c|}
\hline \multirow{2}{*}{$\begin{array}{l}\text { Stream } \\
\text { no. }\end{array}$} & HA & HU & \multicolumn{2}{|c|}{ HA of D } & \multicolumn{2}{c|}{ HA of V } & \multicolumn{2}{c|}{ HU of D } & \multicolumn{2}{c|}{ HU of V } \\
\cline { 4 - 12 }$n$ & N & N & $n_{0.05}$ & $n_{0.03}$ & $n_{0.05}$ & $n_{0.03}$ & $n_{0.05}$ & $n_{0.03}$ & $n_{0.05}$ & $n_{0.03}$ \\
\hline $\mathbf{1}$ & 156 & 117 & 21 & 58 & 50 & 141 & 17 & 47 & 52 & $\mathbf{1 4 4}$ \\
\hline $\mathbf{2}$ & 76 & 201 & 8 & 24 & 49 & $\mathbf{1 3 8}$ & 4 & 12 & 45 & 125 \\
\hline $\mathbf{3}$ & 96 & 106 & 6 & 18 & 92 & $\mathbf{2 5 8}$ & 6 & 71 & 18 & $\mathbf{1 9 9}$ \\
\hline $\mathbf{4}$ & 96 & 49 & 4 & 12 & 28 & 80 & 6 & 15 & 28 & $\mathbf{7 7}$ \\
\hline $\mathbf{5}$ & 96 & 102 & 11 & 32 & 33 & 93 & 14 & 40 & 30 & 82 \\
\hline $\mathbf{6}$ & 114 & 110 & 22 & 62 & 14 & 38 & 9 & 26 & 29 & 81 \\
\hline
\end{tabular}

\section{Table III}

Statistical testing for preference occurrence of depth $(D)$, velocity $(V)$, substrate $(S)$ and cover $(C)$ using Mann-Whitney U-test and contingency table testing of HA and HU. Statistical significance is illustrated using * $(p<0.05),{ }^{* *}(p<0.01),{ }^{* *}(p<0.001)$ and ns (non-significant). Contingency of HA and HU for $C$ was tested against both No Cover (NC) and All Covers (AC).

\begin{tabular}{|c|c|c|c|c|c|c|c|c|}
\hline \multirow{2}{*}{$\begin{array}{l}\text { Stream } \\
\text { no }\end{array}$} & \multicolumn{3}{|c|}{ Mann-Whitney U-test } & \multicolumn{5}{|c|}{ Contingency table test } \\
\hline & D & $\mathbf{V}$ & $S$ & D & V & $S$ & $\mathrm{C}-\mathrm{NC}$ & $C-A C$ \\
\hline 1 & 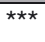 & ns & 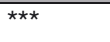 & 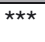 & ns & ** & 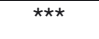 & ** \\
\hline 2 & 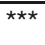 & * & 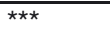 & 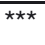 & ** & ** & *** & ** \\
\hline 3 & 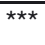 & ns & 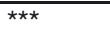 & 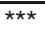 & ns & ns & 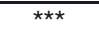 & ** \\
\hline 4 & 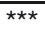 & ns & ** & *** & ns & 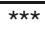 & 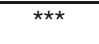 & ** \\
\hline 5 & 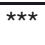 & ns & * & 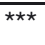 & ns & ns & 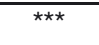 & ** \\
\hline 6 & * & ** & ** & 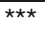 & 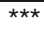 & ns & 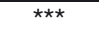 & *夫 \\
\hline
\end{tabular}

in the interval $0.3-0.4 \mathrm{~m}$ except for site 2 where maximum preference is for a lower depth (0.1-0.2 m).

There was only a significant difference between utilised $V$ and available $V$ in sites 2 and 6 (Table III), indicating that parr in the other four sites generally used the same range of $\mathrm{V}$ as was available. In sites 2 and 6 , parr used the $V$ intervals $0.4-0.5 \mathrm{~m} \cdot \mathrm{s}^{-1}$ and $0.1-0.2 \mathrm{~m} \cdot \mathrm{s}^{-1}$ respectively more than what was available indicating preference for these velocity ranges. Parr in all sites except site 2 had the highest HSI for low $V$ (around $0.2 \mathrm{~m} \cdot \mathrm{s}^{-1}$ ) while parr of site 2 preferred higher velocities $\left(0.4 \mathrm{~m} \cdot \mathrm{s}^{-1}\right)$ (Figure 3).

There was a significant difference between median utilised $S$ and available $S$ in all sites (Table III) with parr using larger $S$, indicating preference for coarser substrate (Figure 4). However, distribution of utilised $S$ and available $S$ was only significantly different for sites 1,2 and 4 , indicating that the preference for $\mathrm{S}$ distribution was not consistent. For all sites, HSI was highest for boulder except site 6 where boulder was absent and HSI was highest for pebble (largest substrate available) (Figure 4). The sensitivity analysis showed that the HSI of the boulder category was sensitive to changes in the HA data, with the HSI of other substrate categories changing by as much as $35 \%$ when $\mathrm{HA}$ of boulder was modified by $5 \%$. In order to stabilize the HSls, the number of substrate categories was reduced by joining boulder and cobble into a single category (Stone). Furthermore, pebble and gravel categories were joined to a single category (Gravel), while Sand and Silt remained separate categories. Joining the categories helped to stabilise the substrate HSIs. Parr at all sites still had the highest HSI for the largest substrates available (Figure 4).

Significant differences were found at all sites when comparing the distributions of utilised $\mathrm{C}$ and available $\mathrm{C}$ when cover was compared to no-cover (Table III). In addition significant differences were found between HU and HA for the different cover types (Table III). Parr in all sites had the highest HSI for SOL cover, although sites 3 and 6 also had high HSIs for REV (Figure 5). 

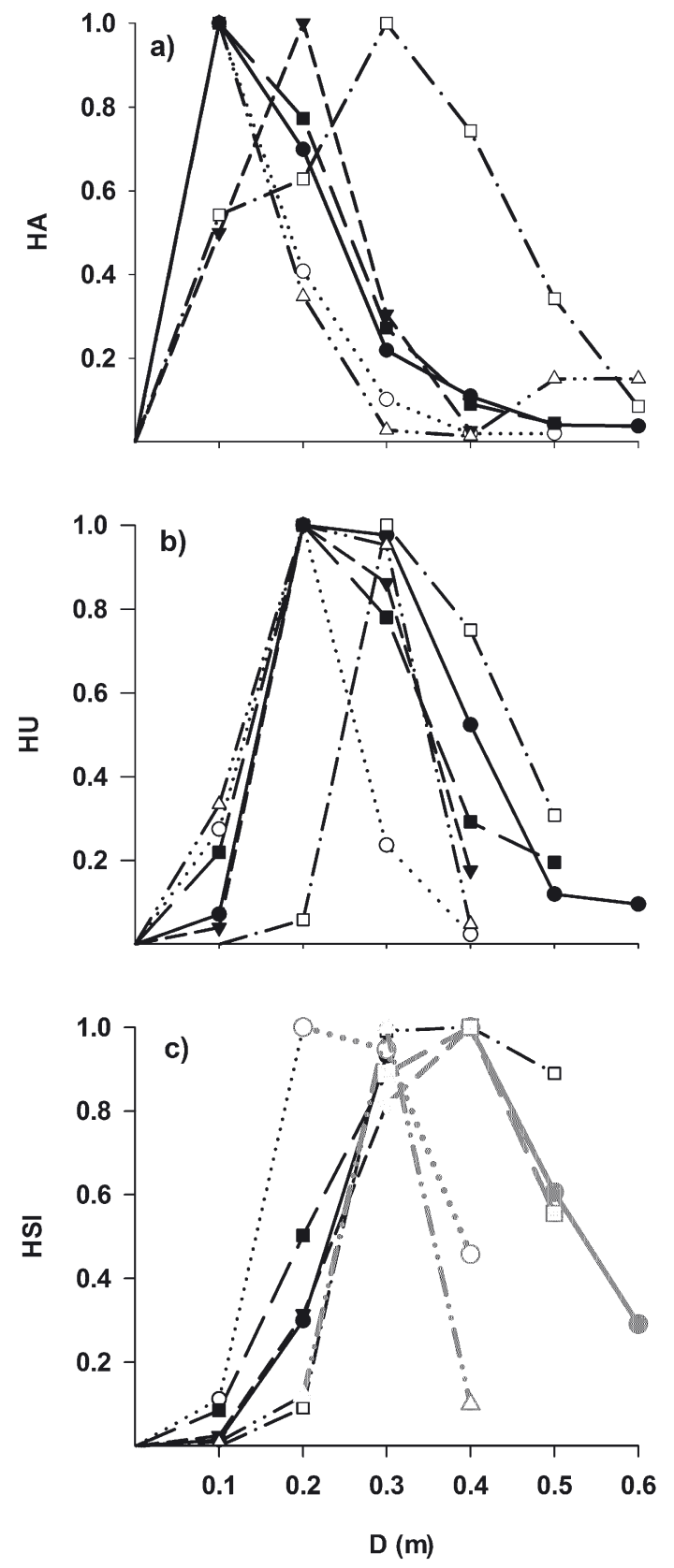

\section{Figure 2}

Habitat availability of depth, $D$ (a), habitat utilization of $D$ (b), and preference based HSIs for $D$ (c), for sites 1-6. Site 1 (filled circle), site 2 (empty circle), site 3 (filled triangle), site 4 (empty triangle), site 5 (filled square) and site 6 (empty square). Grey lines illustrate higher uncertainty preference based HSIs. All data series have been normalized to 1.

\section{DISCUSSION}

Physical habitat is important in determining the carrying capacity and population density of brown trout within streams (Heggenes et al., 1999; Armstrong et al., 2003; Jonsson and Jonsson, 2011). Habitat requirement of brown trout is useful for stream management purposes (Riley et al., 2006; Nislow and Armstrong, 2012). This knowledge is important for development of management plans aimed at attaining good ecological status in streams, as requested by the WFD (Commission 2000). In this study, adequate sampling data was collected for six sites for four habitat variables to be able to assess habitat selection by large brown 

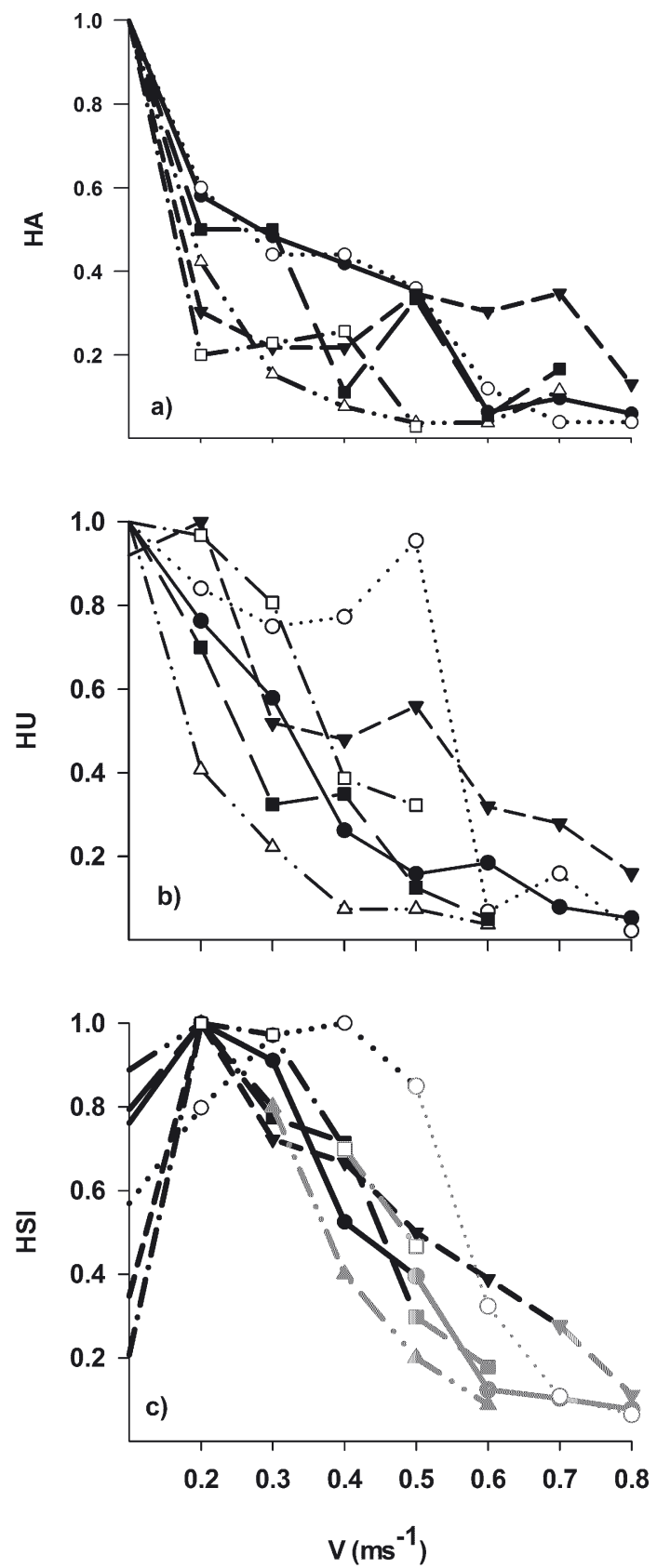

\section{Figure 3}

Habitat availability of velocity, $V(a)$, habitat utilization of $V(b)$, and preference based HSIs for $V$ (c) for sites 1-6. All data series have been normalized to 1.

trout parr. Habitat preference was observed in all six streams, and preference was consistent across all sites for water depth and cover, but more variable for velocity and substrate.

Parr at all sites showed preference for water depth under daytime summer low flow conditions. Previous studies have illustrated the key importance of water depth in determining juvenile brown trout habitat use (Bohlin, 1977; Bagliniere and Champigneulle, 1982; Egglishaw and Shackley, 1982; Kennedy and Strange, 1982; Heggenes, 1988c, d), including Danish small lowland streams (Hermansen and Krog, 1984). All of the above studies and others have shown that there is a positive correlation between fish size and water depth, and that the larger the trout, the deeper water it prefers (Greenberg et al., 1996; Heggenes et al., 1999; Maki-Petays et al., 1997). This preference for deep water could be explained by the 

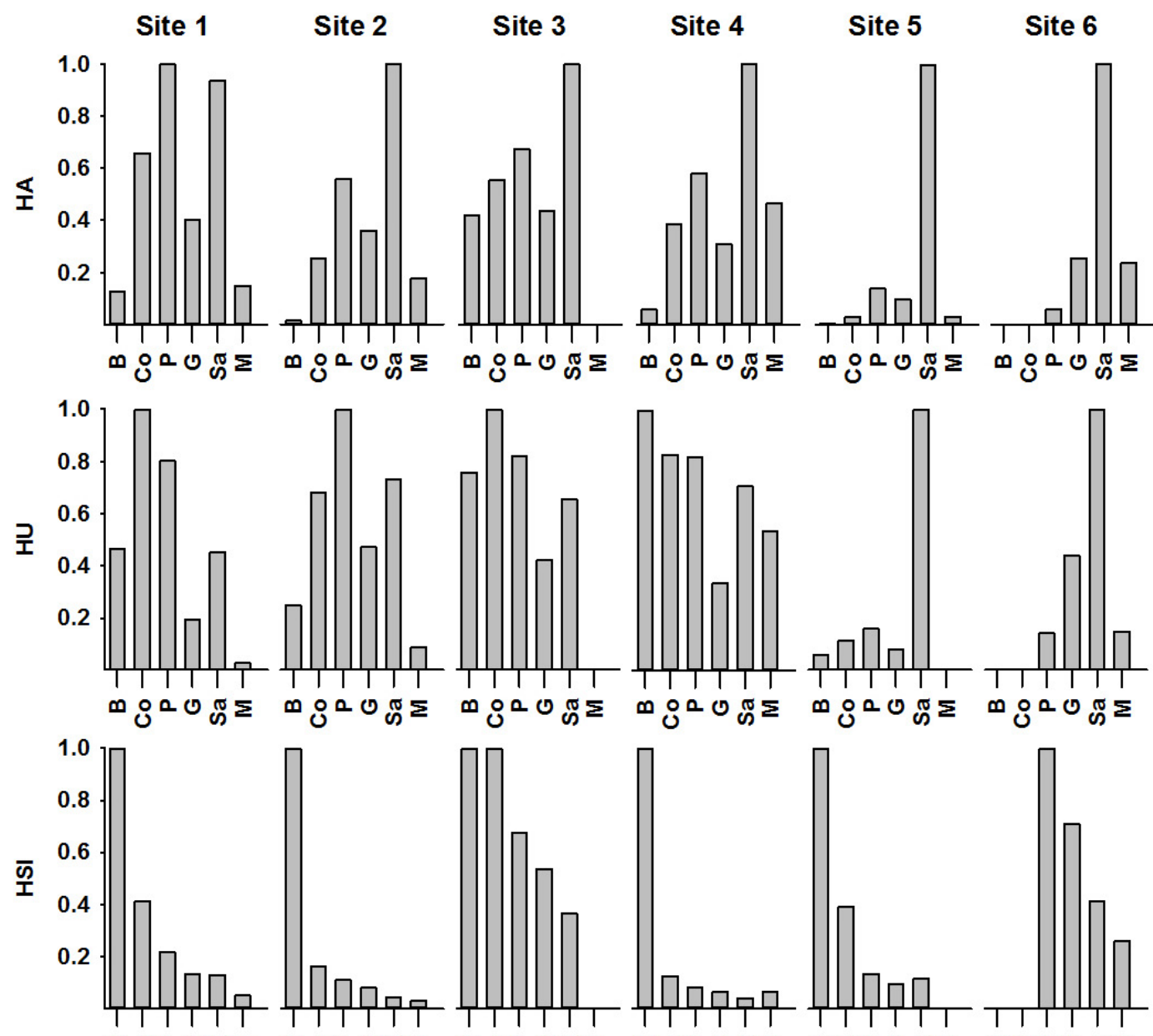

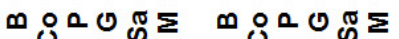
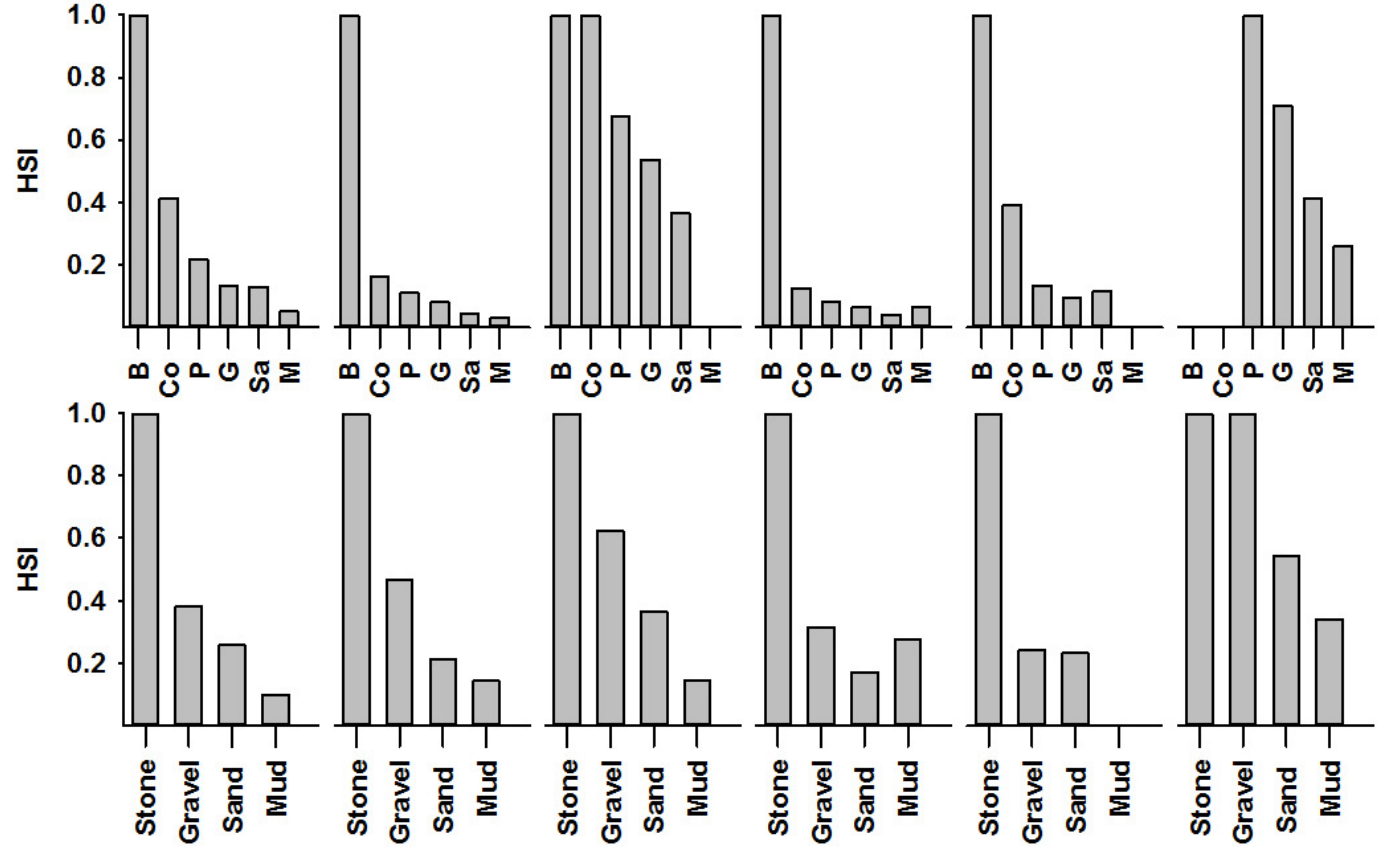

Figure 4

Habitat availability of substrate, $S$ (a), habitat utilization of $S$ (b), preference based HSIs for $S$ (c), and preference based HSI for $S$ which have been corrected for low data availability of rare habitats (d) for sites 1-6. All data series have been normalized to 1.

possibility that parr may primarily be feeding nocturnally during summer (Alvarez and Nicieza 2003; Orpwood et al., 2006; Conallin, 2009; Conallin et al., 2012), and seeking refuge during the day to avoid predation (Aarestrup et al., 2003; Gwiazda and Amirowicz, 2006). Parr in small Danish lowland streams are vulnerable to avian predators such as grey heron (Ardea cinerea) and great cormorants (Phalacrocorax carbo sinensis) (Aarestrup et al., 2003; Jepsen et al., 2010, 2013) which are common species in many European countries. Grey heron has been shown actively to select parr sized fish and to have an effective strike depth up to $0.2 \mathrm{~m}$ (Power, 1987; Gwiazda and Amirowicz, 2006). Depths larger than $0.2 \mathrm{~m}$ are limited in small 

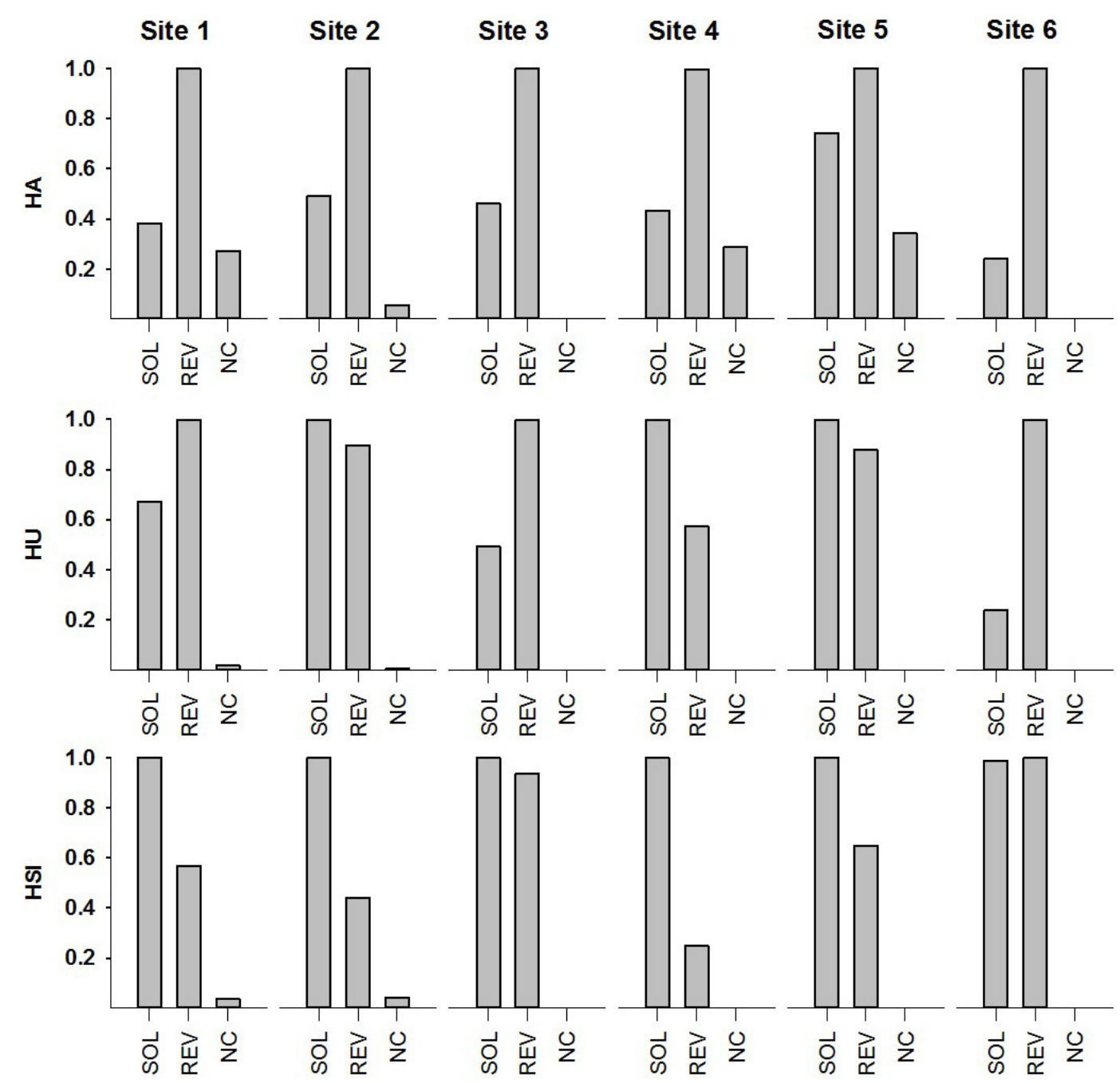

Figure 5

Habitat availability of cover (C), habitat utilization of $C$ (b) and preference based HSls for $C$ (c) for sites 1-6. All data series have been normalized to 1.

Danish lowland streams in summer. Visual assessment of foraging in selected stream sections at each site was carried out under both day and night conditions, and parr were not observed to be actively foraging during the day, although fry were (Conallin, 2009). A laboratory study in Denmark (Conallin et al., 2012) also showed that parr primarily forage nocturnally. When there are relatively few deep areas, such as in the small lowland streams during summer low flow conditions, depth increases in importance (relative to other habitat descriptors) in habitat selection (Dunbar et al., 2001). In addition to depth being used as a cover, other forms of cover are often present in pools, e.g. log jams (Sundbaum and Naslund, 1998), so a combination of covers may coincide with water depth, and parr choosing the combination of covers during the day.

In this study, $H U$ of water velocity had almost the same frequency as $H A$, and in only two sites did parr clearly show preference for water velocity. Velocity HSI was highest in the low velocity intervals $\left(0.1-0.2 \mathrm{~m} \cdot \mathrm{s}^{-1}\right)$ for five of the six sites although only one of the sites showed preference. In site 2, the preference for higher velocities could have been caused by relatively high densities of large parr compared to adequate depth or other cover, so large parr were using broken water caused by increased velocity as a cover. This is supported by the fact that fish in site 2 showed preference for coarse substrates (interstitial spaces provide velocity refuges) and used a high percentage of reduced visibility cover. Velocity is obviously important for any 
drift feeding species (Karlstroem et al., 1977; Cunjak and Power; 1986; Heggenes et al., 1999; Armstrong et al., 2003), but not necessarily in selection for daytime refugia, where variables associated with daytime refugia becomes the most important in relation to selection (Dunbar et al., 2001; Alvarez and Nicieza 2003). It may also be that the range of water velocities available in these small streams (rarely $>0.6 \mathrm{~m} \cdot \mathrm{s}^{-1}$ and mean $0.216 \mathrm{~m} \cdot \mathrm{s}^{-1}$ ) is well within the optimum foraging ranges optimal to parr brown trout (Heggenes and Saltveit, 1990; Heggenes et al., 1999; Maki-Petays et al., 1999, Giroux et al., 2000). Daytime refugia preference could also help explain why parr in general have a wider range of microhabitat velocities than fry that actively forage during the day (Armstrong et al., 2003; Nislow and Armstrong, 2012). In small lowland streams, deeper areas are found in pools where velocity is reduced (at least during summer low flow conditions) (Hermansen and Krog, 1984; Heggenes, 1988d; Dunbar et al., 2001), acting as optimal areas for daytime refugia (Elliot, 2000; Gries and Juanes, 1998). Preference occurred in all sites for mean substrate size, with parr preferring coarser substrates. However, the preference distribution was inconsistent between sites. The inconsistent substrate preference may have been related to boulders being associated with sand in some of the sites. Substrate may be selected as a cover source as parr can find shelter from predators using the interstitial spaces, while minimising energy expenditure (Bachman, 1984; Heggenes et al., 1999; Maki-Petays et al., 1997; Bardonnet and Heland, 1994). Substrate is generally considered very important for parr brown trout as a cover source (Heggenes, 1988b), with preference for coarser over finer substrates (Bachman, 1984; Huusko et al., 1997; Maki-Petays et al., 1997), and with fish size being positively correlated to grain size (Heggenes et al., 1999). Coarse substrate also reduces energy expenditure if fish are using surface tension velocity refuges (Heggenes and Saltveit, 1990; Rincon and Loboncervia, 1993) to act as direct cover from predators. It is known that the parr use the interstitial spaces between the substrate as refuge (Bachman, 1984; Bardonnet and Heland, 1994), and it can provide visual isolation from other juvenile trout (Shuler et al., 1994).

In this study, preference for cover was significant in all sites but the selection between cover types varied among sites with 'solid cover' and to a lesser extent 'reduced visibility cover' being most important. This suggests that in addition to water depth parr will use a range of cover types (Naslund, 1989; Sunbaum and Naslund, 1998), for daytime refuge and possibly select them in relation to energy minimisation, and to minimize intraspecific competition (Shuler et al., 1994; Heggenes et al., 1999). It could also be that the cover preference is combined with more available living space. Other studies have demonstrated strong cover preferences of parr brown trout (Heggenes et al., 1999; Vehanen et al., 2000; Armstrong et al., 2003).

\section{> CONSTRAINTS AND POSSIBLE APPLICATIONS FOR WATER MANAGEMENT}

In order to assess the links between biota and physical habitat for management planning, it is essential that this knowledge is clear and concise, or at least the limitations transparent so that it is best integrated into management applications (Heggenes et al., 1996; Rosenfeld, 2003; Armstrong and Nislow, 2012). Although the results of this study show that parr in Danish small lowland streams do have distinct habitat preference, it should be stressed that the results are restricted to represent daytime conditions for parr brown trout at summer flow discharges. Habitat preference is likely to change over a diel and seasonal period, and within different stream discharges (Cunjak and Power, 1986; Heggenes et al., 1993; Conallin et al., 2012). In addition the results are not applicable to large lowland streams because in situ depth conditions of this study (maximum depth $0.6 \mathrm{~m}$ ) is exceeded in larger streams. Gear bias can also play a significant role in where fish are located (Heggenes et al., 1991; Scruton et al., 2002), and electrofishing (method used in this study) is known to scare foraging fish into refugia (Heggenes and Saltveit, 1990). However, if parr are predominately already using refugia during daytime conditions, fright bias is lessened. Therefore, in small streams where other methods are not applicable (e.g. snorkeling) electrofishing is a viable method to study daytime habitat selection for juvenile brown trout, but not an optimal method for studying foraging habitats for juvenile brown trout. 
Despite these restrictions, which are part of any study, the results are particularly valuable for low flow and habitat management of such streams. Summer low flow condition is a significant limiting factor for brown trout populations in small lowland streams (Elliot et al., 1997; Bell et al., 2000). Instream physical habitat is vulnerable to management activities such as water abstraction impacts on low flow conditions in summer (Henriksen et al., 2008; Olsen et al., 2009), directly impacting on water depth and water velocity. Physical modification of the streams (Brookes, 1987) directly impacts depth and water velocity but also substrate and cover attributes (e.g. boulders, wood) which are closely affiliated with stream management actions, including restoration in small lowland streams. Therefore identifying factors such as depth, cover and substrate as being significant variables (that can be manipulated by management actions), this knowledge can aid in decision making. Furthermore, the developed HSIs from this study are well suited for integrated hydrological-ecological assessments of (ground)water abstraction impacts and stream management activities (including restoration) on physical instream habitat conditions (Thorn and Conallin, 2006; Conallin et al., 2010b; Olsen et al., 2013).

\section{CONCLUSION}

Using the sampling design applied in this study, it was possible to collect sufficient data on habitat availability and habitat use data to determine habitat selection, the importance of particular habitat variables, and if habitat preference was occurring. Water depth was found to be the most significant daytime physical habitat variable for habitat selection by parr brown trout during summertime in small lowland streams in Denmark, with cover and substrate also important. This is most likely related to parr seeking daytime refugia to avoid predation, and possibly feeding at night where velocity would become more important.

For water resource and stream management purposes, the physical habitat variables water depth, cover and substrate are affected by flow and habitat management activities (including restoration), and highlighting their importance in determining habitat requirements for brown trout in small lowland streams will help inform management actions and their possible impacts or effectiveness. In addition the developed HSIs from this study are well suited for integrated hydrological-ecological assessments of (ground)water abstraction impacts, and stream management activities on physical instream habitat conditions.

\section{ACKNOWLEDGEMENTS}

The study was partly funded by the project 'Climate change impact on ecological conditions in streams' financed by the Danish Research Council for Technology and Production (contract no. 274-06-0474).

\section{REFERENCES}

Aarestrup K., Jepsen J., Koed A. and Pedersen S., 2003. Movement and mortality of stocked brown trout in a stream. J. Fish Biol., 66, 721-728.

Acreman M. and Ferguson A., 2010. Environmental flows and the European water framework directive. Fresh. Biol., 55, 32-48.

Almodóvar A., Nicola, G.G., Ayllón D. and Elvira B., 2012. Global warming threatens the persistence of Mediterranean brown trout. Glob. Chang. Biol., 18, 1549-1560.

Alvarez D. and Nicieza A., 2003. Predator avoidance behaviour in wild and hatchery-reared brown trout: the role of experience and domestication. J. Fish Biol., 63, 1565-1571.

Armstrong J.D. and Nislow K.H., 2012. Modelling approaches for relating effects of change in river flow to populations of Atlantic salmon and brown trout. Fish. Manag. Ecol., 19, 527-536. 
Armstrong J.D., Kemp P.S., Kennedy G.J.A., Ladle M. and Milner N.J., 2003. Habitat requirements of Atlantic salmon and brown trout in rivers and streams. Fish. Res., 62, 143-170.

Bachman R.A., 1984. Foraging behaviour of free-ranging wild and hatchery brown trout in a stream. Trans. Am. Fish. Soc., 113, 1-32.

Bagliniere J.L. and Champigneulle A., 1982. Population-density of brown trout (Salmo-trutta-L) and Atlantic salmon (Salmo-salar L) juveniles on the river Scorff (Brittany) - habitat selection and annual variations (1976-1980). Acta Oecologica-Oecologia Applicata, 3, 241-256.

Bain M.B. and Jia H., 2012. A habitat model for fish communities in large streams and small rivers. Int. J. Ecol., 1-8. http://dx.doi.org/10.1155/2012/962071.

Bain M.B. and Stevenson N.J., 1999. Aquatic habitat assessment: common methods. Bethesda, Maryland: American Fisheries Society.

Bardonnet A. and Heland M., 1994. The influence of potential predators on the habitat preference of emerging brown trout. J. Fish Biol., Suppl. A, 131-142.

Bell V.A., Elliott J.M. and Moore R.J., 2000. Modelling the effects of drought on the population of brown trout in Black Brows Beck. Ecol. Model., 127, 141-159.

Bohlin T., 1977. Habitat selection and intercohort competition of juvenile sea-trout Salmo-trutta. Oikos, 29, 112-117.

Bovee K.D., 1986. Development and evaluation of habitat criteria for use in instream flow incremental methodology. In: Instream flow information paper 21 US Fish and Wildlife Service (FWS/OBS/86/07). Fort Collins.

Bovee K.D., Lamb B.L., Barthalow J.M., Stalnaker C.B., Taylor J. and Henriksen J., 1998. Stream habitat analysis using the Instream Flow Incremental Methodology. In: US Geological Survey Biological Resources Discipline Information and Technology Report USGS/BRD-1998-0004. Fort Collins.

Brookes A., 1987. The distribution and management of channelised streams in Denmark. Regulated Rivers: Research and Management, 1, 3-16.

Clausen B. and Jensen J.L., 1994. CALQ - A new program to calculate the river discharge. In: Nordic Hydrological Conference, Thorshavn, Faroe Islands, 24 August 1994. NHP-report, (34), 525-532.

Commission E., 2000. Directive 2000/60/EC. Establishing a framework for community action in the field of water policy In: European Commission PE-CONS 3639/1/100 Rev 1. Luxembourg.

Conallin J., 2009. Instream Physical Habitat Suitability Modelling in Danish small lowland streams: The development of Habitat Suitability Indices for juvenile brown trout (Salmo trutta). Ph.D. Thesis. Department of Environment, Social and Spatial Change (ENSPAC), Roskilde University, Denmark.

Conallin J., Boegh E. and Jensen J.K., 2010a. Instream physical habitat modeling types: an analysis as stream hydromorphological modelling tools for EU water resource managers. Int. J. River Basin Management, 8, 93-107.

Conallin J., Olsen M., Boegh E., Jensen J.K. and Pedersen S., 2010b. Habitat suitability indices development in Denmark: are international indices applicable under small lowland stream conditions? Int. J. River Basin Management, 8, 151-160.

Conallin J.C., Jyde M., Filrup K. and Pedersen S., 2012. Shelter use of juvenile brown trout (Salmo trutta) under laboratory conditions in Denmark. Knowl. Managt. Aquatic Ecosyst., 404, 1-6.

Cunjak R.A. and Power G., 1986. Winter habitat utilization by stream resident brook trout (Salvelinusfontinalis) and brown trout (Salmo-trutta). Can. J. Fish. Aquat. Sci., 43, 1970-1981.

Dunbar M., Ibbotson A., Gowing I., McDonnell N., Acreman M. and Pinder A., 2001. Further validation of PHABSIM for the habitat requirements of salmonid fish. In: R\&D Report W6-036. Centre for Ecology and Hydrology, UK.

Edmondson W.T. and Winberg G.G., 1971. A manual on methods for the assessment of secondary productivity in fresh waters. Oxford, Blackwell.

Egglishaw H.J. and Shackley P.E., 1982. Influence of water depth on dispersion of juvenile salmonids, Salmo-salar L and Salmo-trutta-L, in a Scottish stream. J. Fish Biol., 21, 141-155.

Elliott J.M. 2000. Pools as refugia for brown trout during two summer droughts: Trout responses to thermal and oxygen stress. J. Fish Biol., 56, 938-948.

Elliott J.M., Hurley M.A. and Elliott J.A. 1997. Variable effects of droughts on the density of a sea-trout Salmo trutta population over 30 years. J. Appl. Ecol., 34, 1229-1238. 
Falke J.A., Fausch K.D., Magelky R., Aldred A., Durnford D.S., Riley L. K. and Oad R. 2011. The role of groundwater pumping and drought in shaping ecological futures for stream fishes in a dryland river basin of the western Great Plains, USA. Ecohydrology, 4, 682-697.

Friberg N., Baattrup-Pedersen A., Pedersen M. and Skriver J., 2005. The new Danish stream monitoring programme (NOVANA) - Preparing monitoring activities for the water framework directive era. Environmental Monitoring and Assessment, 111, 27-42.

Giroux F., Ovidio M., Philippart J.C. and Baras E., 2000. Relationship between the drift of macroinvertebrates and the activity of brown trout in a small stream. J. Fish Biol., 56, 1248-1257.

Greenberg L., Svendsen P. and Harby A., 1996. Availability of microhabitats and their use by brown trout (Salmo trutta) and grayling (Thymallus thymallus) in the River Vojman, Sweden, 287-303.

Gries G. and Juanes F., 1998. Microhabitat use by juvenile Atlantic salmon (Salmo salar) sheltering during the day in summer. Can. J. Zool. Rev. Can. Zool., 76, 1441-1449.

Gwiazda R. and Amirowicz A., 2006. Selective foraging of Grey Heron (Ardea cinerea) in relation to density and composition of the littoral fish community in a submontane dam reservoir. Waterbirds, 29, 226-232.

Heggenes J., 1988a. Effect of experimentally increased intraspecific competition on sedentary adult brown trout (Salmo-trutta) movement and stream habitat choice. Can. J. Fish. Aquat. Sci., 45, 1163-1172.

Heggenes J., 1988b. Effects of short-term flow fluctuations on displacement of, and habitat use by, brown trout in a small stream. Trans. Am. Fish. Soc., 117, 336-344.

Heggenes J., 1988c. Physical habitat selection by brown trout (Salmo trutta) in riverine systems. Nordic J. Fresh. Resources, 64, 74-90.

Heggenes J., 1988d. Substrate preferences of brown trout fry (Salmo-trutta) in artificial stream channels. Can. J. Fish. Aquat. Sci., 45, 1801-1806.

Heggenes J., 2002. Flexible summer habitat selection by wild, allopatric brown trout in lotic environments. Trans. Am. Fish. Soci., 131, 287-298.

Heggenes J. and Dokk JG., 2001. Contrasting temperatures, waterflows, and light: Seasonal habitat selection by young Atlantic salmon and brown trout in a boreonemoral river. Regulated RiversResearch \& Management, 17, 623-635.

Heggenes J. and Saltveit S.J., 1990. Seasonal and spatial microhabitat selection and segregation in young Atlantic salmon, Salmo-salar L, and brown trout, Salmo-trutta L, in a Norwegian river. J. Fish Biol., 36, 707-720.

Heggenes J. and Traaen T., 1988. Downstream migration and critical water velocities in stream channels for fry of 4 salmonid species. J. Fish Biol., 32, 717-727.

Heggenes J., Krog O.M.W., Lindas O.R., Dokk J.G. and Bremnes T., 1993. Homeostatic behavioralresponses in a changing environment - brown trout (Salmo-trutta) become nocturnal during winter. J. Anim. Ecol., 62, 295-308.

Heggenes J., Braband S.J. and Saltveit, 1991. Microhabitat use by brown trout, Salmo trutta L. and Atlantic salmon, S. salar L., in a stream: a comparative study of underwater and river bank observations. J. Fish Biol., 38, 259-266.

Heggenes J., Saltveit J. and Lingaas O., 1996. Predicting fish habitat use to changes in water flow: Modelling critical minimum flows for Atlantic salmon, Salmo salar, and brown trout, S-trutta. River Res. Appl., 12, 331-344.

Heggenes J., Bagliniere J.L. and Cunjak R.A., 1999. Spatial niche variability for young Atlantic salmon (Salmo salar) and brown trout (S. trutta) in heterogenous streams. Ecol. Fresh. Fish, 8, 1-21.

Heggenes J., Saltveit S.J., Bird D., Grew R., 2002. Static habitat partitioning and dynamic selection by sympatric young Atlantic salmon and brown trout in south-west England streams. J. Fish Biol., $60,72-86$.

Henriksen H.J., Troldborg L., Hojberg A.L. and Refsgaard J.C., 2008. Assessment of exploitable groundwater resources of Denmark by use of ensemble resource indicators and a numerical groundwatersurface water model. J. Hydrol., 348, 224-240.

Hermansen H. and Krog C., 1984. Influence of physical factors on density of stocked brown trout (Salmo-trutta-fario L) in a Danish lowland stream. Fisheries Managt., 15, 107-115.

Hubert W.A., Harris D.D. and Wesche T.A., 1994. Diurnal shifts in use of summer habitat by age-0 brown trout in a regulated mountain stream. Hydrobiologia, 284, 147-156. 
Huusko A. and Yryana T., 1997. Effects of instream enhancement structures on brown trout, Salmo trutta L. habitat availability in a channelized boreal river: a PHABSIM approach. Fish. Managt. Ecol., 4, 453-466.

Jepsen N., Sonnesen P., Klenke R. and Bregnballe T., 2010. The use of coded wire tags to estimate cormorant predation on fish stocks in an estuary. Mar. Freshw. Biol., 61, 320-329.

Jepsen N., Skov C. and Pedersen S., 2013. Overview of the effects of predation on freshwater fish stocks. Report for Technical University of Denmark - AQUA, National Institute of Aquatic Resources, Department of Inland Fisheries.

Jonsson B. and Jonsson N., 2011. Habitat Use. In: Jonsson B. and Jonsson N. (eds.), Ecology of Atlantic Salmon and Brown Trout. Fish \& Fisheries Series Volume 33, 2011, pp. 67-135. DOI 10.1007/97894-007-1189-1.

Karlstroem 1977. Habitat selection and population densities of salmon (Salmo salar L.) and trout (Salmo trutta L.) parr in Swedish rivers with some references to human activities. Acta Universitatis Upsaliensis, 404, 1-12.

Kennedy G.J.A. and Strange C.D., 1982. The distribution of salmonids in upland streams in relation to depth and gradient. J. Fish Biol., 20, 579-591.

Knapp R.A. and Preisler H.K., 1999. Is it possible to predict habitat use by spawning salmonids? A test using California golden trout (Oncorhynchus mykiss aguabonita). Can. J. Fish. Aquat. Sci., 56, 1576-1584.

Kondolf G.M., 2000. Assessing salmonid spawning gravel quality. Trans. Am. Fish. Soc., 129, $262-281$.

Krebs C.J., 1998. Ecological Methodology, Second edition edition. Benjamin Cummings.

Maki-Petays A., Muotka T., Huusko A., Tikkanen P., Kreivi P., 1997. Seasonal changes in habitat use and preference by juvenile brown trout, Salmo trutta, in a northern boreal river. Can. J. Fish. Aquat. Sci., 54, 520-530.

Maki-Petays A., Muotka T. and Huusko A., 1999. Densities of juvenile brown trout (Salmo trutta) in two subarctic rivers: assessing the predictive capability of habitat preference indices. Can. J. Fish. Aquat. Sci., 56, 1420-1427.

Mortensen E., 1977. Density-dependent mortality of trout fry (Salmo-trutta L) and its relationship to management of small streams. J. Fish Biol., 11, 613-617.

Mortensen E., 1982. Production of trout, Salmo-trutta, in a Danish stream. Environ. Biol. Fishes, 7, 349-356.

Mortensen E., 1985. Population and energy dynamics of trout Salmo-trutta in a small Danish stream. J. Anim. Ecol., 54, 869-882.

Naslund I., 1989. Effects of habitat improvement on brown trout Salmo trutta L., population of a northern Swedish stream. Aquaculture and Fisheries Management, 30, 463-474.

Nislow K.H. and Armstrong J.D., 2012. Towards a life-history-based management framework for effects on flow on juvenile salmonids in streams and rivers. J. Fish. Managt. Ecol., 19, 451-463.

Olsen M., Boegh E., Pedersen S. and Pedersen M.F., 2009. Impact of groundwater abstraction on physical habitat of brown trout (Salmo trutta) in a small Danish stream. Hydrol. Res., 40, 394-405.

Olsen M., Troldborg L., Henriksen H.J., Conallin J., Refsgaard H.C. and Boegh E., 2013. Evaluation of a typical hydrological model in relation to environmental flows. J. Hydrol., 507, 52-62.

Orpwood J.E., Griffiths S.W. and Armstrong J.D., 2006. Effects of food availability on temporal activity patterns: safety first for salmon in summer. J. Fish Biol., 67, 272-273.

Parasiewicz P., 2007. Using MesoHABSIM to develop reference habitat template and ecological management scenarios. River Research and Applications, 23, 924-932.

Parasiewicz P. and Dunbar M.J., 2001. Physical habitat modelling for fish - a developing approach. Large Rivers, 12, 239-268.

Power M.E., 1987. Predator avoidance by grazing fishes in temperate and tropical streams: importance of stream depth and prey size, p. 333-351. In: Kerfoot W.C. and Sih A. (eds.), Predation: direct and indirect impacts on aquatic communities. Hanover: Univ. Press, New England.

Procopio N.A., 2012. The effect of streamflow reductions on aquatic habitat availability and fish and macroinvertebrate assemblages in coastal plain streams. Ecohydrology, 5, 306-315.

Quinn G.P. and Keough M.J., 2006. Experimental Design and Data analysis for Biologists. Cambridge: Cambridge University Press. 
Riley W.D., Ives M.J., Pawson M.G, Maxwell D.L., 2006. Seasonal variation in habitat use by salmon, Salmo salar, trout, Salmo trutta and grayling, Thymallus thymallus, in a chalk stream. Fish. Managt. Ecol., 13, 221-236.

Rincon P.A. and Loboncervia J., 1993. Microhabitat use by stream-resident brown trout - bioenergetic consequences. Transactions of the American Fisheries Society, 122, 575-587.

Rosenfeld J., 2003. Assessing the habitat requirements of stream fishes: An overview and evaluation of different approaches. Trans. Am. Fish. Soc., 132, 953-968.

Roussel J.M., Bardonnet A., 2002. The habitat of juvenile brown trout (Salmo trutta L.) in small streams: Preferences, movements, diel and seasonal variations. Bulletin Francais De La Pêche Et De La Pisciculture, 365-66, 435-454.

Sand-Jensen K. and Friberg N., 2006. Streams and their future inhabitants. In: Sand-Jensen K. Friberg N. and Murphy J. (eds.), Running Waters, Silkeborg, Denmark, Schultz Grafisks.

Scruton D.A., Scruton Clarke K.D., Ollerhead L.M.N., Perry D., McKinley R.S., Alfredsen K. and Harby A., 2002. Use of telemetry in the development and application of biological criteria for habitat hydraulic modeling. Hydrobiologia, 483, 71-82.

Shuler S.W., Nehring B.R. and Fausch K.D., 1994. Diel habitat selection of brown trout in the Rio Grande River, Colorado, after placement of boulders. North American J. Fish. Managt., 14, 99-111.

Sundbaum K. and Naslund I., 1998. Effects of woody debris on the growth and behaviour of brown trout in experimental stream channels. Can. J. Zool. Rev. Can. Zool., 76, 56-61.

Thorn P. and Conallin J.C., 2006. RHYHABSIM as a stream management tool: Case study in the River Kornerup Catchment, Denmark. The Journal of Transdisciplinary Environmental Studies, 5, 1-17.

Vehanen T., Bjerke P.L., Heggenes J., Huusko A. and Maki-Petays A., 2000. Effect of fluctuating flow and temperature on cover type selection and behaviour by juvenile brown trout in artificial flumes. J. Fish Biol., 56, 923-937.

Vezza P., Parasiewicz P., Rosso M. and Comoglio C., 2012. Defining minimum environmental flows at a regional scale: Applications of mesoscale habitat model and catchment classification. River Research and Application, 28, 717-730. 